among the many questions on which light may be thrown by the photographs which have been secured in Siam, and which it was hoped would have been duplicated in the Bay of Bengal. As the prismatic camera was the instrument requiring least time for adjustment, so it was the one which could be employed for the longest period during the eclipse. Before and after totality it may have done good service by recording the constitution of the lower part of the sun's atmosphere in a manner which it will not be very difficult to interpret, though certainly the characters will be of the strangest."

\section{ARCTIC GEOLOGY*}

\section{III.}

Const of Arctic America-Melville Peninsula.Amongst the rock specimens brought home by Dr. Rae, Prof. Tennant recognised gneiss, hornblende slate, and similar metamorphic rocks, a portion probably of the granitic and crystalline rocks described by Sir John Richardson as occupying the central and eastern countries of the Hudson's Bay territory, believed by Sir R. Niurchison to belong to the Laurentian system. The latter points out that from the prevalence of a profusion of Upper Silurian corals characteristic of the Niagara and Onondaga limestones (Wenlock or Dudley), the trilobite Encrinurus punctatus, and the shell Pentamerus oblongus, in the rocks lying on the Laurentian, in the north of the Hudson's Bay territory, and the absence of any traces of Lower Silurian rocks or fossils in the whole of the inown polar region, that it is in the highest degree probable that the whole of the country north of the Laurentian Mountains was dry land during the deposition of the Lower Silurian. In the area to the south, and in Europe, and even in the Upper Silurian times, the sea, as evidenced by the presence of $P_{\text {enta- }}$ merus, was not a deep one, which is borne out by Sir W. Logan's discovery that the Silurian limestones at the head of Lake. Temiscamang include enormous blocks of the sandstone on which they rest. +

Boothia. - Chalky limestones occur, but do not contain fossils, as at Prince of Wales Island, where the Esquimaux obtain large quanitities of native copper on the shore.

Sir James Ross $\$$ describes the River Saumarez, lat. 7o, long. $92 \mathrm{~W}$., as never frozen, and gives a sketch showing the gorge 80 feet in depth, excavated in hard trap, in which it runs. In the month of July he found several butterflies living near the coast, including an Hippar. chia, two species of Colias, one being near $C$. edusa, and a Polyommatus. In Agnew River he found copper ore.

West Coast of Bafin Sea.-Crystalline rocks extend from Lancaster Sound to Cape Walter Bathurst and Cumberland Sound, with the exception of Cape Durban, where coal has been found by the whalers, a continuation probably of that of Disco ; it also occurs at Kingaiti, two degrees south of Durban, as well as pure graphite. $\$$

Arctic Archipelago.-Dr. Haughton, from an examination of the rocks and fossils collected by Sir Leopold $\mathrm{M}^{\text {'Clin- }}$ tock from 1849 to 1859 , now deposited in the museum of the Royal Dublin Society, was enabled to draw up a geological map of the Arctic Archipelago,\| in which Silurian limestone is shown to occupy nearly all the islands south of Lancaster and Melville Sounds, including the south side of Banks Land, Prince Albert Land, Prince of Wales Land, King William's Island, and Boothia Felix, the central and western area of North Devon, and the whole of Cornwallis Island, \&c. ; granitoid rocks occurred on either side of Peel Sound, and at Ponds Bay, and

* Continued from p. 469.

Narrative of Expedition to Shores of Arctic Sea. By John Rae. I Narrative of Second Yoyage in Learch of 1872 . Ross. 1835 .

II "Quar. Jour. Geol, Soc., vol. ix. near the mouth of the Fish River; also the eastern coast of North Devon and the opposite side of Baffin Bay, to $77^{\circ}$ north latitude.

The lower carboniferous close-grained white sandstone ("Ursa stage" of Heer), with beds of coal, strikes S.W. and N.E. from Baring or Banks Land, where it rests on the Silurian, through Melville Island to Bathurst Island, where it disappears under the carboniferous limestone between Penny Strait and Queen's Channel.

The carboniferous limestone appears to strike nearly east and west; the whole of Prince Patrick Island is composed of it, and the northward portion of Parry Islands and the whole of Grinnell Land ; ${ }^{*}$ scattered over the limestone on several points are patches of lias, in which fossils have been found, notably at Intrepid Inlet, Arnott Bay, Bathurst Island, and on Exmouth Island north of Grinnell Land.

North Devon.--From Cape Osborne to Cape Warrender graphic granite occurs, passing into laminated gneiss consisting of black mica and transparent felspar, interstratified with garnetiferous mica-slate, traversed by epidote hornstone overlaid by red sandstone, similar to that of Wolstenholme Sound.

Dr. Sutherland describes the crevasses of the glaciers of Petowak, on the south coast of Jones Sound, as often being filled with mud, which becomes frozen in, and the whole mass breaks off in bergs.

North Somerset.-Granite of grey quartz, red felspar, and green chloritic mica occurs on the west coast. Eastward, the island consists of the Upper Silurian sandstones and limestones, the junction of which occurs in Transition Valley. In Bellot Straits granite and syenite rise to a height of 1,600 feet. The base of the Silurian consists of red sandstone and coarse grit, resembling those of Cape Warrender and Wolstenholme Sound, overlaid by ferruginous limestones with quartz grains, earthy limestones, occasionally cream-colcured, dipping from $0^{\circ}$ to $5^{\circ}$ to the N.N.W.; a few high cliffs occur, but the country is generally low and terraced, the limestone standing out as steps and butiresses, particularly at Port Leopold, where the alternation of hard limestone and soft shales, so well known in Euronean limestone districts, is well shown in Beechey's sketch, at p. 35 of Parry's First Voyage. Amongst the fossils from Port Leopold Di: Haughton records Loxonema $M^{6} C$ Cintockiz, and specimens of carielian and selenite.

Prince of Wales Island.-Eruptive syenite occurs at Cape $M$ 'Clure. The western coast consists of Silurian limestone with fossils, overlaid by bright red ferruginous limestones, and a few beds of bright red sandstones, like the Transition Valley sandstone.

BanEs Land.-Upper Silurian rocks are succeeded by close-grained sandstone, striking N.E. to E.N.E., of Lower Carboniferous age, and containing thin coal seams, discovered first in Parry Islands by Parry, and afterwards by Austin and Belcher in Melville Island and Bathurst Island. The fossils from this series are similar to those from the Irish Calp series, and from the Eifel. Silicified stems of plants were discovered by $\mathrm{M}^{\prime} \mathrm{Clure}$ on the coast of Banks Land, and on those of Wellington Channel by Belcher. The southern entrance to this channel was discovered by Sir Edward Parry in 1819. The lamented Sir John Franklin sailed up it 150 miles in 1845 , before being beset with ice at Beechey Island in September 1846 .

In Drift on the Coxcomb Range, Banks Land, M'Clure found fine specimens of Cyprina Istandica, 500 feet above the sea. In $78^{\circ} \mathrm{N}$., Belcher found whale bones on high ground; and marine shells are described by Parry as occurring in clay in the ravines of Byam Martin's Island.

From the coast of Princess Royal Island the Esquimaux procure native copper in large masses. The rocks consist of greyishiyellow sandstone, with Terebratula aspersa.

* The north-west cornex of North Dezion, not the large tract west of Kennedy Channel. 
Melville Island.-Several coal seams occur in the sandstones beneath the carboniferous limestone, striking about E.N.E. The coal burns with a bright flame, with much smoke, and resembles some of the gas coals of Scotland.

In Eglinton Island, between Melville Island and Prince Patrick's, carboniferous limestone with siliceous and ferruginous grits occur, capped by a patch of lias; and highly crystalline gypsum was found N.W. of Melville Island.

Byam Martin Isiand.-Two sandstones occur, one soft streaky, passing into purple sandstone like that of Wolstenholme Sound, the other fine grained, greyishyellow, with coal seams, like that of Cape Hamilton, Baring Island, containing Terebratula primipilaris, Von Buch, and several Eifel forms, and of therefore Upper Silurian or Devonian species. The coal seams occur at a height of 350 feet above the sea, and are described as lignites by Salter.

Exmouth, Table, and Princess Islands, between North Cornwall and North Devon, with Depot Point on the north coast of the latter, form a remarkably fossiliferous area, from which a large number of fossils were collected by $\mathrm{Sir}$ Edward Belcher in 1855 , and described by the late Mr. Salter.* Exmouth Island $\left(77^{\circ} \mathrm{N}\right.$. lat. and $95^{\circ} \mathrm{W}$. long.) rises to a height of 570 feet; the base is soft sandstone abruptly terminating except to the west, overlaid by limestone dipping to the west at $7^{\circ}$, containing Zaphrentis, Spirifer Keilhavii, and other species of carboniferous limestone type; at the top a patch of lias occurs, from which the vertebræ and ribs were collected by Belcher, determined by Prof. Owen to belong to an Ichthyosaurus near to $I$. acutus of the Whitby Lias.

Lias fossils had previously been discovered by Lieut. Anjou, of the Russian Navy, and described by Wrangel, from New Siberia in Asia, in $74^{\circ}$ N. lat., but the presence of lias in these high latitudes remained unnoticed until Be!cher's discovery at Exmouth Island, after which several fossils were brought home by Sir Leopold M'Clintock and Admiral Sherard Osborne, amongst them Ammonite $M$ 'Clintockii of Haughton. $\dagger$ A remarkably fossiliferous patch of lias also occurs at Point Wilkie, in Prince Patrick's Island, resting on carboniferous limestones, \&c.

Rhynchonella of Silurian species were found by the Rev. Longmuir in the ballast of a ship from the coast of Prince Albert's Land; it is worthy of note that one species of Fhynchonella, R. psittacea, still lives on in these Arctic Seas, and, according to Mr. Gwyn Jeffreys, as far south as Drontheim.

Cornwallis Islands consist of Silurian rocks with Syrincopora geniculata. On its coast and on that of Beechey Island Dr. Sutherland describes marine glacial drift, with Arctic shells, as occurring up to a height of I, COO feet above the sea, and the presence of blocks of granite and anthracite on the shores of Lancaster Sound, brought by coast-ice.

At Dundas Island, in lat. $76^{\circ}$ I $5^{\prime}$, one of Capt. Penny's crew found a Silurian trilobite, and preserved it, tied in his shirt, when the toat had to be abandoned and a retreat effected. The presence of Silurian rocks at a point so far north, and of sandstones at Wolstenholme Sound, appears to render it probable that the E.N.E. strike of the Carboniferous strata, with their overlying Liassic patches, is cut off eastward, and the Silurian rocks surround them in a basin-like form, an E.N.E. synclinal running through Prince Patrick Island towards Hayes Sound. Detailed examination of the west coast of Smith Sound and Kennedy Channel will have great geological interest, as it will prove whether such a synclinal exists, and if so, whether the Carboniferous rocks are brought in by it, and whether the lower coal-

* "Last of the Arctic Voyages by Sir E. Belcher." (London, 1855.) + Appendix to "Voyage of the Fo:x" bearing measures are present on both sides of it, and in what manner they rest on the Silurians of Grinnell Land. Grinnell Land.-From the cliffs of Lady Franklin Bay and from Cape Frazer, in lat. $81^{\circ} 35^{\prime}$ N., long. $70^{\circ}$ $\mathrm{W}^{r}$., Dr. Hayes found thirteen species of fossils, which were identified by Prof. Meek as Upper Silurian species, belonging to the fauna found in the New York Catskill Shaley Limestone of the Lower Helderberg group. Some of the species, as Zaphrentis Haysii, Meek, and Loxonema Kanei, Meek, are new to science.* One of the most northern promontories of Grinnell Land is named after the late Sir Roderick Murchison, who, commenting on the collections brought from the Arctic Archipelago by Parry, Franklin, Ross, Back, Austin, Ommaney, ard the private expeditions of Lady Franklin, particularly those of Penny and Inglefield, and by the expedition under Sir E. Belcher, endorses the results arrived at by Mr. Salter, that the larger number of fossils obtained belong to Upper Silurian species of rather an American than a European facies, though many species were identical with those of Wenlock, Dudley, and Gothland.t Dr. Conybeare had, in his Report on Geology to the British Association in 1832 , already noticed the similarity of the fossils from the Arctic regions to those of the English Upper Silurian series.

Dr. Emil Bessels, the naturalist of the American Polaris Expedition under the late Capt. Hall, who bad previously taken part in the Prussian Polar Expedition, reports the most northern known land on the east side of the channel, including that portion of Hall's Land examined, to consist of Upper Silurian rocks, with a few fossils. .

The Esquimaux inhabitants of the coasts of Arctic America, trom Behring's Straits to Greenland, speak the same language, and use similar implements. There is no more interesting passage in Prof. Dawkins' recent work than that in which he compares the identity of type of these implements with those from Dordogne and other parts of France and Belgium, both as regards fowling and fishing spears, darts, and arrows ; this likeness extends to the actual shape of the base of insertion into the haft, the haft being formed of mammoth ivory derived from the frozen cliffs, of the very species that was hunted by palæolithic man in the South of France.

These two peoples, separated so widely in time and space, were alike in their artistic feelings and methods of incising, on tusks, antlers, and bones, representations of familiar objects; alike also in their habit of splitting bones for marrow and accumulating them around their dwellings, in their disregard for the sepulchre of their dead, in their preparation of skins for clothing, and in the pattern of the needles used in sewing them together; alike also in their feeding on the musk sheep and the reindeer, and in countless other characteristics. It is well-nigh impossible to resist Prof. Dawkins' conclusion that the Esquimaux is the descendant of palæolithic man, who retreated northwards with the Arctic fauna with which he lived in Europe: though before the close of the glacial epoch it is probable that a continuous land connection existed between France and North America by way of Siberia, remains of the true horse having been discovered associated with Bison priscus and the mammoth in Arctic America, and representations of the horse, by a palæolithic artist, occurring on an antler from La Madelaine, and the entire skeleton of a horse from a palæolithic station being preserved in the Lyons Museum.

Sir John Richardson II speaks of the Kuskutchchewak people who inhabit the banks of a river flowing

* American fournal of Science and Arts, second series, vol. xl., No. I1 8,1865

† "Open Polar Sea " (London, 1867 ), pp. 440, et seq. " Siluria," 1872 . 5th edition, p. 44t.

\pm Bull. Soc. Geog. Paris, March 1875 . I have to thank Captain Feilden, R.A., naturalist to the Arctic Expedition, for calling my attention to this letter of Dr. Bessels.

" "Cave Hunting." (London: Macmillan, $x 874$.

II "Arctic Search Expedition." (London, 185x.) 
into Kuskokvim Bay, Behring Sea, as believing that the mammoth, whose tusks they constantly find came from the east, and were destroyed by the spells of their shaman.

In the kitchen-middens of the deserted Esquimaux villages of Jacobshafn, West Greenland, Dr. Oberg discovered bones of the Walrus and Cystophora cristata, which no longer ventures into this ice-blockaded fjord; and also of the bear Ursus maritimus, which is now rarely seen south of the Waigat, associated with arrowheads, stone flakes, and scrapers, of clear quartz crystals and green jasper (angmak of the Greenlanders), found in the basalt of Disco.

\section{Charles E. DE RANCE}

(To be continued.)

\section{ON ATTRACTION AND REPULSION RESULT - ING FROM RADIATION}

$A T$ the Royal Society conversazzone the other evening A the most interesting object exhibited was, beyond all doubt, the radiometer of Mr. Crookes. Mr. Crookes' discovery is of so much importance that our readers will be glad to have an abstract of a paper on the subject, recently read by $\mathrm{Mr}$. Crookes at the Royal Society. was the second part of a paper which the author sent to that Society in August 1873 .

Mr. Crookes commences by describing improvements which he has made in the Sprengel pump, and in various accessories which are necessary when working at the highest rarefactions. He describes different new forms which enable the phenomena of repulsion by radiation to be observed and illustrated. A bulb three inches diameter is blown at the end of a glass tube eighteen inches long. In this bulb a fine glass stem with a sphere or disc of pith, \&r., at each end is suspended by means of a cocoon fibre. The whole is attached to the Sprengel pump in such a way that it can be perfectly exhausted, and then hermetically sealed. Besides pith, the terminals may be made of cork, ivory, metal, or other substance. During exhaustion several precautions have to be taken, and to get the greatest delicacy in an apparatus of this kind, there is required large surface with a minimum of weight. An apparatus constructed with the proper precautions is so sensitive to heat that a touch with the fnner on a part of the globe near one extremity of the pith will drive the index round over $90^{\circ}$, whilst it follows a piece of ice as a needle follows a magnet. With a large bulb very well exhausted and containing a suspended bar of pith, a somewhat striking effect is produced when a lighted candle is placed about two inches from the globe. 'The pith-bar commences to oscillate to and fro, the swing gradually increasing in amplitude until the dead centre is passed over, when several complete revolutions are made. The torsion of the suspending fibre now offers resistance to the revolutions, and the bar commences to turn in the opposite direction. This movement is kept up with great energy and regularity as long as the candle burns.

Mr. Crookes discusses the action of ice, or a cold substance, on the suspended index. Cold being simply negative heat, it is not at first sight obvious how it can produce the opposite effect to heat. The author, however, explains this by the law of exchanges, and shows that attraction by a cold body is really repulsion by radiation falling on the opposite side. According to the same law, it is not difficult to foresee what will be the action of two bodies, each free to move, if they are brought near to each other in space, and if they differ in temperature either from each other or from the limiting walls of the space. The author gives four typical cases, with experiments, which prove his reasoning to be correct.

Experiments are descriled with the object of ascer- taining whether the attraction by heat, which, commencing at the neutral point, increases with the density of the enclosed air, will be continued in the same ratio if the apparatus is filled with air above the atmospheric pres. sure. This is found to be the case. Various experiments are described with bulb-apparatus, in which the bulb is surrounded with a shell containing various adiathermous liquids, and also with a shell of vacuum. In all cases radiation passed through, producing the normal action of attraction in air and repulsion in a vacuum.

Mr. Crookes next describes a form of apparatus by which measurable results are attainable. It consists of a long glass tube, with a wider piece at the end. In it is suspended a lump of magnesium by a very fine platinum wire, the distance between the point of suspension and the centre of gravity of the magnesium bob being $39^{\circ}$ I 4 inches. Near the magnesium is a platinum spiral, capable of being ignited by a voltaic battery. Observations of the movement of the pendulum were made with a telescope with micrometer eyepiece. With this apparatus a large series of experiments are described, starting from air of normal density, and working at intermediate pressures up to the best attainable vacuum.

With this apparatus it was found that a candle-flame brought within a few inches of the magnesium weight, or its image focussed on the weight, and alternately obscured and exposed by a piece of card at intervals of one second, will soon set the pendulum in vibration when the vacuum is very good. A ray of sunlight allowed to fall once on the pendulum will immediately set it swinging.

The form of apparatus is next described, which the author has finally adopted, as combining the greatest delicacy with facility of obtaining accurate observations, and therefore of getting quantitative as well as qualitative results. It consists of a glass apparatus in the shape of an inverted $T$, and containing a horizontal glass beam suspended by a very fine glass thread. At the extremities of the beam are attached the substances to be experimented on, and at the centre of the beam is a small mirror from which a ray of light is refiected on to a graduated scale. The advantage which a glass thread possesses over a cocoon fibre is that the index always comes accurately back to zero. In order to keep the luminous index at zero, except when experiments are being tricd, extreme precautions must be taken to keep all extraneous radiation from acting on the torsion-balance. The whole apparatus is closely packed all round with a layer of coiton-wool about six inches thick, and outside this is arranged a double row of Winchester quart bottles filled with water, spaces only being left for the radiation to fall on the balance, and for the index ray of light to get to the mirror.

However much the results may vary when the vacuum is imperfect, with an apparatus of this kind they always agree amongst themselves when the residual gas is re duced to the minimum possible; and it is of no consequence what this residual gas is. Thus, starting with the apparatus full of various vapours and gases, such as air, carbonic acid, water, iodine, hydrogen, ammonia, \&c., at the highest rarefaction there is not found any difference in the results which can be traced to the residual gas. A hydrogen vacuum appears the same as a water or an iodine vacuum.

With this apparatus the effect of exposing torsionbalance to a continuous radiation is described, and the results are shown graphically. The effect of a short ( $11^{*} 3$ seconds) exposure to radiation is next described, and the results are given in the form of a Table.

In another Table are given the results of experiments in which a constant source of radiation was allowed to act upon one end of the torsion-beam at a distance of 140 or 280 millims., various substances being interposed. The sensitiveness of this apparatus to heat-rays appears to be greater than that of an ordinary themo-multiplier. Thus 